\title{
Partial special issue entitled Selected Papers from the International Symposium on Wind and Tidal Power, 28-31 May 2017, Montreal, Québec, Canada
}

\author{
Special Editor \\ Pierre Sullivan \\ University of Toronto
}

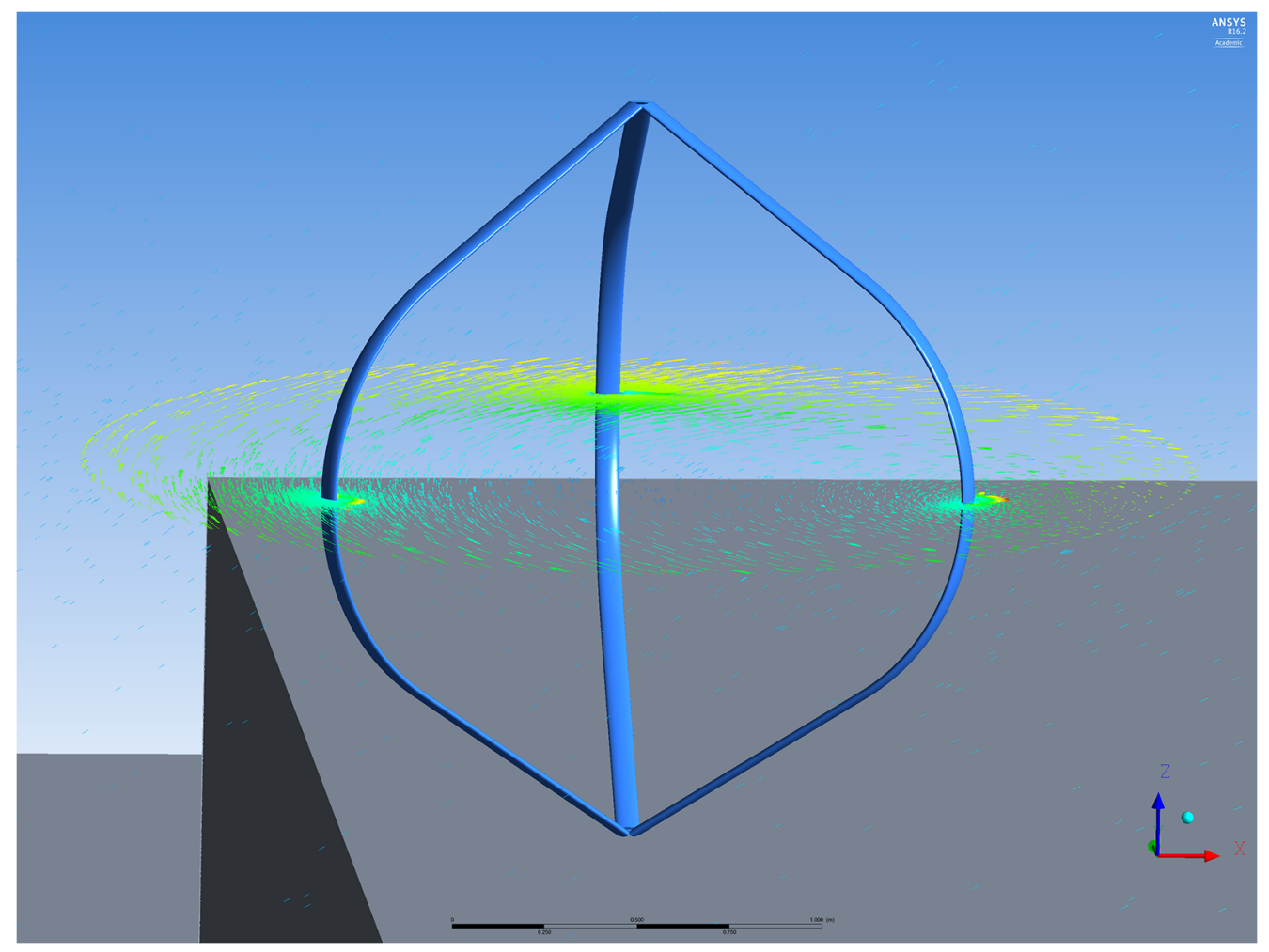

